\title{
Evolution and future trends of copyright in Nigeria
}

\author{
Kunle Ola*
}

\begin{abstract}
This chapter examines the development of copyright in Nigeria by looking at the different legal regimes that have existed within Nigeria's copyright system. It provides an historical perspective of the development of Copyright law in Nigeria by tracing the introduction of the first indigenous copyright law in Nigeria and the current copyright legislation into the Nigerian legal system. The chapter highlights the issues with the first indigenous copyright legislation, discusses some of the provisions of the Act, and the subsidiary legislations that have been issued. It also examines the role of the Nigerian Copyright Commission as the agency saddled with the responsibility of administering Nigeria's Copyright Laws. The chapter concludes with thoughts on the future for copyright in Nigeria.
\end{abstract}

Keywords: copyright law, Nigeria, licensing, openness of justice system

\section{Introduction}

1.1 Creativity. Creativity gives expression to the ideas in the human soul. Every culture reveals an intrinsic part of itself through the creativity of her people. The Director of the Museum of Fine Arts in Boston commenting on some Nigerian artistic works said "These objects are the Benin Kingdom's legacy to the world and a testament to the brilliance and creativity of its artists". ${ }^{1}$ The works he referred to were 34 in number, 28 made of bronze and 6 of ivory and are currently displayed at the Benin Kingdom Gallery of the Museum of Fine Arts in Boston. ${ }^{2}$ These works include what the gallery describes as "Horseman, Battle Plaque, Double Gong, and Oba Dominating Leopards". 3

\footnotetext{
* Kunle Ola is currently a PhD Research Candidate at the Australian Catholic University and a Principal Copyright Officer at the Nigerian Copyright Commission.

${ }^{1}$ MFA, Museum of Fine Arts, Boston, Opens Benin Kingdom Gallery Showcasing Robert Owen Lehman Collection of Rare West African Art(2013), available at www.mfa.org/news/benin_kingdom.

${ }^{2}$ MFA, Benin Kingdom Gallery Gallery 172, Museum of Fine Arts Boston(2013), available at: www.mfa.org/collections/featured-galleries/benin-kingdom-gallery.

3 Tajudeen Sowole, U.S. Museum Splits Benin Royal House, THE GuARDian, 29 September 2013. 2013.
} 
1.2 Iyoba. Seating in another Museum outside the shores of Nigeria is a bone ivory sculpture known as the Queen Mother Pendant Mask-"Iyoba". Iyoba is a sculptured work of Idia, who was the Queen mother of Oba Esigie, an ancient monarch of the Bini's now part of the people of Nigeria and located in Edo State in the mid-western part of Nigeria ${ }^{4}$. The sculptured work dates back to the $16^{\text {th }}$ century and its presence at the Metropolitan Museum in London serves as a reminder to the world of the creative genius of Nigerians. ${ }^{5}$

1.3 Nigeria. Nigeria is a country with over, one hundred and sixty (160) million people, five hundred ethnic groups, two hundred and fifty (250) local languages (however, English is the official language), thirty-six (36) states, a Federal Capital Territory (Abuja) and seven hundred and seventy four (774) local government councils. It is the most populous African nation and the $7^{\text {th }}$ most populous in the world. ${ }^{6}$ It has a dual mixed culture, one from its traditional background and the other from its British colonial heritage. Her people are distinct in culture, tradition, belief and religion and it is these differences that bring about an enriched cultural diversity and a uniqueness in the expression of her creativity.

Nigeria's rich cultural diversity plays a key role in the creative expressions of her people and has a strong influence on the copyright based works created by Nigerians. The rise in the Nigerian entertainment industry, popularly known as Nollywood has put Nigeria on the limelight both in the music and film industries. It is therefore not surprising that Nigeria's film industry has been rated as the third largest in the world after Hollywood of the United States and Bollywood of India. ${ }^{7}$ These creative works continue to lay credence to the creative capabilities of Nigerians and underscores the

\footnotetext{
${ }^{4}$ The Bini's are now referred to Benin's of the Federal Republic of Nigeria and this should not be confused with Benin Republic.

${ }^{5}$ Metropoitan Museum of Arts, Queen Mother Pendant Mask: Iyoba. On Display in Gallery 352., available at http://www.metmuseum.org/collections/search-thecollections/318622.

6 Federal Republic of Nigeria, About Nigeria, available at http://www.nigeria.gov.ng/2012-10-29-11-05-46.

${ }^{7}$ Assessing the participation of domestic SMEs in the international production chain: The case of $\mathrm{Nu}$ Metro in Nigeria. (2010). available at http://unctad.org/en/Docs/diaeed20095_en.pdf
} 
need to encourage further creativity by putting in place a strong and viable copyright system.

Creativity is the bedrock of every civilization and it encourages the transformation of ideas into tangible products such as articles, books, pictures, films, drawings, music, poems and drama amongst several other things. Appreciation of the value of these tangibly expressed ideas often lead to commercialisation of the products. This was the situation that occurred in the United Kingdom when printers were enabled by the invention of the printing press to commercialise the writings of popular authors. ${ }^{8}$ This practice by printers to commercially exploit the literary works of authors must have been due to the fact that printers recognised an appeal by the general public to some works and that such works if mass produced could be commercially viable. The challenge was that commercialisation of these works meant reproduction of the works and this was done without the consent of authors and apparently, with no financial benefits accruing to them. This practice gave rise to complaints and agitations which brought about the introduction of the first copyright law to protect the rights of authors to their literary works by the grant of exclusive rights to the work, for a specified period of time. ${ }^{9}$

Since the passage to law of the first copyright legislation, the Statute of Anne $^{10}$, many copyright legislations have been passed by national governments and the International community. ${ }^{11}$ These legislations underscore the importance of copyright and rights related to copyright also referred to as neighbouring rights to national and socio-economic development. Nigeria is one of the nations with a copyright legislation ${ }^{12}$ and plays her role within the International copyright system.

\footnotetext{
${ }^{8}$ Chris Butler, FC74: The invention of the printing press and its effects at http://www.flowofhistory.com/units/west/11/FC74

9 Olukunle OlA, Copyright Collective Administration in Nigeria LESSONS FOR AFRICA 6-7 (Springer. 2013).

${ }^{10}$ Statute of Anne, 8 Anne c. 19 (1710)

${ }^{11}$ wipo, wipo administered treaties, available at http://www.wipo.int/treaties/en/. Wipo provides a comprehensive list of all national and international copyright legislations

${ }^{12}$ Nigerian Copyright Act, Cap C28 (2004).
} 


\section{What is copyright}

2.1 Definition. Before venturing into the historical perspective of how Copyright began, it would be useful to understand the term Copyright. Copyright is a legal system that protects the creative outputs of authors by granting them exclusive rights to control the use of their creations for a limited time, subject to certain limitations, exceptions and statutory licensing arrangements allowing use and exploitation without the author's consent. Copyright is one of the two major heads of the field known as Intellectual Property and Intellectual Property has been defined by the World Intellectual Property Organisation (WIPO) as "creations of the mind: inventions, literary and artistic works, and symbols, names, images, and designs used in commerce". ${ }^{13}$ Whereas, inventions, symbols, names and designs used in commerce are majorly under the other head of Intellectual Property known as Industrial property; Copyright covers literary, artistic, musical and dramatic works. It also covers under a copyright related rights regime, broadcast, sound recording and cinematograph film works.

2.2 Purpose. Two purposes will be considered, economic and moral. With regards to the economic purpose, copyright encourages creativity and provides a legal regime for recouping investments put into products of creativity by granting authors exclusive rights to control the exploitation of these products for a specified period of time. ${ }^{14}$ On the moral side, copyright protects the integrity of the created work by giving the author the right to object to any distortion, mutilation or other modifications which would be prejudicial to his honour or reputation ${ }^{15}$.

In achieving the economic and moral purposes of copyright, the copyright system as a whole strives to provide balance between the interest of the author and that of the user. Copyright therefore aims to ensure that the public has some form of access to the products that have been created. After all, the whole essence of externally expressing an inward idea is for public appreciation, maximal utility of the expressed idea and for the

\footnotetext{
13 WIPO, What is Intellectual Property, available at http://www.wipo.int/about$\mathrm{ip} / \mathrm{en} /$.

${ }^{14}$ Section 6 (1) Cap C28 (2004). where it states "copyright ... shall be the exclusive right to control the doing in Nigeria of the following..."

${ }^{15}$ Id. at.Section 12 (b).
} 
betterment of mankind ${ }^{16}$. Copyright is therefore meant to play some form of balancing role; that is, balancing the proprietary economic interests of the author in exploiting his created works against that of the public, to wit, accessibility to such created works by the public.

2.3 No Formality Required. Once a work is created, copyright is automatically conferred and its enjoyment and exercise is not subject to any form of formalities. This no formality standard for conferment of copyright stems from a series of meeting which resulted in the Berne Convention, where it was agreed that no formality requirement be placed on the exercise and enjoyment of copyright. ${ }^{17}$ In other words, once a work has been created, it ought to enjoy the protections conferred by copyright without the need to comply with formality such as registration. It is however important to note that certain countries practice some form of registration or recordation systems for copyright but none of them make it a prerequisite for the conferment of copyright. ${ }^{18}$

2.4 Recordation System \& Notification Scheme. The United States Copyright Law has a recordation system which requires registration of copyright, but it clearly notes that registration does not prevent automatic conferment of copyright once a work has been created. ${ }^{19}$ However, in the event of copyright infringements, works originating in the United States but which have not been registered cannot be filed in respect of an infringement suit and are therefore not eligible for enforcement except they are registered. ${ }^{20}$

\footnotetext{
16 Brian FitzGerald, et al., OAK LAW PROJECT NO. 1: Creating a Legal FRAMEWORK FOR COPYRIGHT MANAGEMENT OF OPEN ACCESS WITHIN THE Australian ACADEMiC AND RESEARCh SeCtor (REPORT FOR tHe DEPARTMENT OF EDUCATION AND SCIENCE AND TRAINING (DEST) 80 (2006). Where it was noted that "the whole purpose is information is to be shared as the purpose of bread is to be eaten"

${ }^{17}$ Section 5(2) Berne Convention for the Protection of Literary and Artistic Works, September 9, 1886, amended last on September 28, 1979 (September 9, 1886).

18 W I P O, Copyright Registration and Documentation, available at http:/www.wipo.int/copyright/en/activities/copyright_registration/.

${ }^{19}$ Section 408 The Copyright Act of 1976 Title 17 of United States Code (1976).

${ }^{20}$ Id. at. Sections 411 and 412.
} 
Nigeria also has a recordation system called the Notification Scheme. ${ }^{21}$ It is not a mandatory registration scheme but rather a platform to enable authors give notice of the existence of their work in which copyright subsists. Unlike the recordation system in the United States, failure by a copyright owner to notify the Nigerian Copyright Commission through the notification scheme on the existence of a work does not affect the right of a copyright owner to commence an action in respect of an infringement suit requiring enforcement. This scheme takes its source from one of the mandates of the agency responsible for regulating and administering Copyright in Nigeria. ${ }^{22}$ The Nigerian Copyright Commission (NCC), established by virtue of Section 34 of the Nigerian Copyright Act is responsible among other things for maintaining an effective data bank of authors and their works. The Notification scheme is the mechanism through which records of authors and their works are received and through which the databank is maintained. The Commission's notification scheme will be discussed later in the paper.

2.5 Idea Expression Dichotomy. Copyright does not protect ideas and discoveries but may protect the form in which they are expressed. For a work to be eligible for copyright protection it must show that sufficient effort has been expended on making the work to give it an original character. The work must also be in a fixed and definite form. ${ }^{23}$

\section{Historical perspective}

3.1 King Diarmund \& Statute of Anne. The history of copyright law cannot be told without reference to the Statute of Anne and truly the Statute is an important reference point to the legal expression of copyright but in reality copyright predates the Statute of Anne and has a longer historical origin than 1710. The Declaration by King Diarmund while passing judgement in respect of the dispute between Finnanin and Columcille in the $6^{\text {th }}$ century in Ireland is said to have ushered copyright into the world ${ }^{24}$. The issue that lead to the declaration was that Finnanin accused Columcille of

\footnotetext{
21 NCC, General Information on Copyright Notification Scheme, available at http://www.copyright.gov.ng/index.php/regulatory-schemes/copyright-notification.

${ }^{22}$ See Section 34 (3) eCap C28 (2004).Section 34 in general provides for the establishment of the Nigerian Copyright Commission.

${ }^{23}$ Section 1(2) a\&b, id. at.

${ }^{24}$ Gurry Francis, Re-Thinking the Role of Intellectual Property, WIPO (2013).
} 
copying his bible without his permission and requested that Columcille return the copied work to him. Columcille pleaded in defence that the copy made from the original copy did not take anything away from the original copy and hence no wrong could have been done. In making his decision, King Diarmund declared that "to every cow her calf; and to every book its copy" 25 . This declaration set in motion the principles that protect works of creativity and established that creative works and in this case, a book had the right to enjoy protection against unauthorized exploitation. This same principle has provided guidance in the development of copyright through the ages even to this present day.

3.2 English Copyright Act 1911. Nigeria's copyright history is deeply connected to that of the United Kingdom because of the colonial linkage. Nigeria's copyright history can be traced from two perspectives. The first traces the history to economic and political interests by the United Kingdom which could have been linked to the growing dependence by Nigerians on literary, artistic, musical and other copyright related works originating from the west. During Britain's colonial rule over Nigeria which lasted for 60 years, ${ }^{26}$ a new copyright legislation replacing the Statute of Anne was passed and by virtue of the extension order in council of 1912 of the English Copyright Act of 1911, the English Copyright law became applicable in the Southern Protectorate of Nigeria. The introduction of the English Copyright Law to Nigeria represents the first perspective. The second is of the opinion that copyright has been and is an intrinsic part of the customs and traditions of the people of Nigeria. This view points to the practice where dancers and singers pay homage to their ancestors and predecessors in the trade before they commence their performances. The intent for acknowledgement is the traditional believe that if the current performers desire to succeed, homage must be paid to their ancestors and predecessors in the trade and such homage will attract the requisite blessings. They also point to the practice where money, gifts, refreshment and other forms of remuneration is given to the performers in appreciation and recognition of their performances. ${ }^{27}$ All these practices go to the root of the modern copyright concepts of moral and economic rights. Both

\footnotetext{
${ }^{25}$ Royal Irish Academy, MS 24, 25. See also, Thomas Cahill, How The Irish Saved Civilization, Anchor Books, Doubleday, New York, New York, 1995, p.14. 170.
}

26 World History,History of Nigeria, available at http://www.historyworld.net/wrldhis/plaintexthistories.asp?historyid=ad41.Nigeria was under British Colonization from 1900 till 1960 when she gained her Independence. British interests in Nigeria however predates 1900.

${ }^{27}$ Adebambo Adewopo, NIGERIAN COPYRIGHT SYSTEM: Principles and Perspectives (Odade Publishers. 2012). 
perspectives support the importance of respect, appreciation and some form of remuneration for the efforts of those who have produced creative works. It is without contention however that the extension of the English Copyright Act of 1911 to Nigeria in 1912 introduced into Nigeria's legal system, a copyright legal framework.

The introduction of the English Copyright Act of 1911, (hereinafter referred to as CA 1911) in Nigeria made very little impact on the ordinary Nigerian's day to day life and this was probably due to cultural differences between the people that originated the CA of 1911 and those to whom it was now being applied in Nigeria. At the time of the enactment of the CA 1911, writing had become a way of life in the United Kingdom, expressing ideas be they original or non-original in fixed tangible forms had become the general mode of communication and constituted important elements in the 'fixation and originality' requirements for what would qualify as a copyright work. ${ }^{28}$ In Nigeria however, the predominant mode of communication at the time was through verbal and non-written modes. Information was passed down from one generation to the other verbally, that is through word of mouth. Songs were composed and given life not by it's been written down but by it been sung. Many a times, singers pick up their inspiration while performing and songs are delivered extempore. The audience is the only living evidence that the songs exist. Excluding sculptures and other artistic works which were naturally expressed in fixed form, musical and dramatic works were expressed verbally and were rarely expressed as literary works. ${ }^{29}$

Furthermore, the Nigerian tradition that favours communal ownership and encourages the spirit of camaraderie and free sharing was at variance with the individualistic and proprietary nature of the modern concepts of copyright. In the eyes of the ordinary person, the laws did not exist and would have been regarded as just another administrative process introduced by the colonial masters. The Act however provided the first legislative framework for Nigeria's administration of a copyright system and provided the basis for further development of Copyright laws in Nigeria. This Act continued in force through independence in 1960 until 1970 when the first indigenous Copyright Act was promulgated.

\footnotetext{
28 JenNifer Davis, Intellectual Property LaW 28 (Nicola Padfield ed., Oxford University Press Third ed. 2008). Particularly at 2.12, 2.14 \& 2.15

${ }^{29}$ John Asein, Nigerian Copyright LAW AND Practice (Books and Gavel Limited 2nd ed. 2012).
} 
3.3 The Copyright Act, 1970. The 1970 Act was passed as a decree on the $24^{\text {th }}$ day of December in 1970 under the then General Gowon led military government of Nigeria. The legislation had twenty (20) sections and three (3) schedules. It provided for works eligible for copyright, conferment of copyright, nature of copyright in certain works, first ownership, assignment and licensing, infringement and actions for infringement. The Act provided powers for the appointment of a competent authority to resolve copyright licensing conflicts but the said powers were never activated throughout the life of the legislation..$^{30}$ Nigeria being a party to the Universal Copyright Convention (UCC) ${ }^{31}$ provided for reciprocal extension of protection and placed restrictions on importation of printed copies. Reliance on copyright deriving its source from common law rights were abrogated and the enactment allowed for the making of regulations to fill any lacuna which the enactment left out or which may arise. The sections providing for repeals, transitions and saving provisions as well the Interpretations and citation sections were the last three sections.

The First Schedule to the Act provided for the term of copyright and interestingly reduced the term of copyright from 50 years after the death of the author as reflected in the earlier CA 1911 legislation to 25 years for literary, musical and artistic works. For photographs it provided for 25 years after the end of the year in which the work was first published in contrast to that of the CA 1911 which provided for 50 years from the making of the original. That amounted to a 25 years reduction.

The Copyright Act 1970 being the first indigenous act was expected to protect the Nigerian interest and be reflective of the peculiarities of her people as well as their culture and traditions. This may have accounted for why it cut down the term of copyright to 25 years from 50 years, after all the Nigerian traditional culture is more disposed to a culture of sharing as opposed to the proprietary system. The cut down has however been viewed as a negative move in that the Nigerian copyright owners expected to have retained at least the same rights provided by a non-indigenous legislation

\footnotetext{
${ }^{30}$ OLA, Copyright Collective Administration in Nigeria Lessons for Africa 28. 2013.

${ }^{31}$ UNESCO, Universal Copyright Convention, with Appendix Declaration relating to Article XVII and Resolution concerning Article XI. Geneva, 6 September 1952, available at

http://www.unesco.org/eri/la/convention.asp?KO=15381\&language=E.
} 
and that the indigenous legislation would provide enhanced and more favourable rights, instead it cut down on the term of copyright and was in general terms a watered-down version of the English Copyright Act of 1911. The Act while making provisions on copyright failed to designate any particular authority to oversee copyright issues in Nigeria. The legislation was basically a lame duck and at this time the local copyright based industry in Nigeria was beginning to grow and required a firm policy structure to support this local industry from a local and international perspective. ${ }^{32}$ Concerns about the lacuna in the 1970 act lead to agitations in the copyright based industries which eventually led to the 1988 Copyright Act. Okoroji captured the frustration succinctly when he said

"The very weak provisions of Decree No 61 of 1970, the copyright law then in force, was identified as the major obstacle to effective confrontation of the copyright problem. The civil provisions were cumbersome and had many loop holes... The criminal sanctions... were laughable. There was no provision for any imprisonment. There was therefore very little legal deterrent against piracy... It became very clear that the most important and urgent task ... was to get an effective copyright law promulgated in Nigeria." 33

3.4 The 1988 Copyright Act. The end of the Nigerian civil war in 1970 coincided with Nigeria's oil boom which brought immense wealth to Nigeria. With lots of money to spend and people needing to get back their lives, entertainment offered comfort and further developed into an important industry in Nigeria. Highlife was in high demand and the likes of Sir Victor Uwaifo, Osita Osadebe, Victor Olaiya, Cardinal Rex, Jim Lawson and Celestine Ukwu met these entertainment needs through life performances and productions with Philips Ijora Causeway studios in Lagos Nigeria. Philips which later became phonogram was not the only point of production at the time, there was also Polygram which later became Premier and then EMI which changed to Ivory, DECCA and then Afrodisia. Popular Nigerian artists such as Fela Anikulapo Ransome-Kuti known for his Afro-beat Music, Sunny Okosun for his popular singles

\footnotetext{
${ }^{32}$ Wikipedia, Music of Nigeria, available at http://en.wikipedia.org/wiki/Music_of_Nigeria\#The_1950s.2C_.2760s_and_.2770s

${ }^{33}$ Tony Okoroji, Copyright Neighbouring Rights \& THE New Millionaires (THE TWISTS AND TURNS IN NIGERIA) (Tops Limited. 2008).
} 
"Fire in Soweto" and Mother \& Child", Bongos Ikwue for "Beautiful woman" all produced with EMI. EMI also sold foreign produced works, such as those of Bob Marley, Peter Tosh, Jimmy Cliff and Jonny Nash amongst several others. Indigenous producers were also thriving and made big hits. Homzy Sounds produced the popular "Love Nwantinti" performed by Nelly Uchendu. Another indigenous producer was Rogers All stars who produced what may be regarded as one of Nigeria's most impacting songs "Sweet Mother" performed by Prince Nico Mbarga and the Rocafil Jazz Orchestra. ${ }^{34}$ In the midst of all these developments in the entertainment industry, technological development enabled the invention of the cassette player and cassettes which further brought about cheaper and easier copying. A proliferation of facilities to mass produce works on cassettes brought about piracy challenges in the entertainment industry. Producers, authors and performers were all concerned about the high level of piracy. ${ }^{35}$ The same effects were being felt in the publishing industry as well. This led to setting up an Anti-Piracy Vanguard made up of the music and publishing industries. ${ }^{36}$ Despite several anti-piracy raids and collaborations with the police, piracy was on the rise and the copyright law which had been recently passed had no teeth to bit and therefore did not deter the pirates from their acts. The Nigerian copyright industry frustrated and agitated identified legislative reform as one of the cardinal issues in combatting the challenges posed by piracy. After series of meetings and lobbying the 1988 Copyright legislation was passed and became a part of the Nigerian legal system.

The Act was promulgated under a military administration and was therefore passed as a decree. The Act has been amended twice, firstly in 1992 and secondly in 1999. In 2004, the laws were re-codified under the laws of the federation of Nigeria. The recodification changed the numbering of the sections but its contents are still the same. The Act when passed in 1988 had 41 sections but the combined effect of the recodification and the amendments to the Act has moved the number of sections to 53 sections

\footnotetext{
${ }^{34}$ Okoroji, Copyright Neighbouring Rights \& the New Millionaires (the twists and turns in Nigeria). 2008.

${ }^{35}$ Nigerian Copyright COMmission, SURVEY OF COPYRIGHT PIRACY IN NigERIA (Management Review Limited. 2008). See the foreword at page V.

${ }^{36}$ Okoroji, Copyright Neighbouring Rights \& the New Millionaires (the twists and turns in Nigeria), 2008.
} 
while retaining the original number of parts and schedules, that is, 4 parts and 5 schedules.

The four parts provide for the following:

Part I: Copyright,

Part II: Neigbouring rights,

Part III: Administration of copyright and

Part IV: Miscellaneous.

The five schedules to the act cover the following:

First Schedule: Terms of copyright,

Second Schedule: Exceptions from copyright control

Third Schedule: Special exceptions in respect of a sound recording of a musical work respectively.

Fourth Schedule: Compulsory licences for translation and reproduction of certain works

Fifth Schedule: Translation and savings provisions.

3.5 Works Eligible for Copyright under the Act. Works eligible for Copyright the world over are generally similar but there exist some differences depending on the jurisdiction. Under the Nigerian Copyright Act, six works are particularly mentioned as eligible for copyright. They are as follows: literary, musical and artistic works; cinematograph films, sound recordings and broadcasts. ${ }^{37}$ The first three works form the core of copyright while the last three, are bye products of the first three. They are the economic and commercial end of the first three and are referred to as neighbouring or related rights. Therefore in the discussions on copyright in this section, the focus will be on the first three (literary, musical and artistic) and when reference is made to the last three (cinematograph films, sound recordings and broadcasts), it is in respect of neighbouring rights.

For a work to be eligible for copyright under the act, sufficient effort must have been expended on the work to give it an original character and it must have been fixed in a definite medium directly perceivable or perceivable with the aid of any device or machine. ${ }^{38}$ The fact that the making of a work

\footnotetext{
${ }^{37}$ Section 1 (1) (a)-(f) Cap C28 (2004).

${ }^{38}$ Id. at.Section 1 (2) (a) \& (b)
} 
involved some form of copyright infringement would not alone constitute grounds for ineligibility. ${ }^{39}$

3.6 Conferment of Copyright. Once a work is eligible for copyright, copyright may be conferred on such a work through a number of channels.

i. By virtue of nationality or domicile: The author(s) is a citizen of or is domiciled in Nigeria or an organisation/company duly registered under the laws of Nigeria. ${ }^{40}$

ii. By reference to country of origin: The work was first published or made in Nigeria. ${ }^{41}$

iii. In Works of government, State authorities and International bodies: The work is made under the direction of the government, a state authority or an international body. ${ }^{42}$

iv. Reference to International agreements: The work is made by a person who on the date of the first publication of the work, such person was a citizen of a country or domiciled in a country to which Nigeria is a party to an obligation in a treaty or other international agreement; or where the work was first published in a country where Nigeria has treaty obligations, or where it was first published in either of the following organisations, the United Nations or any of its specialised agencies, the African Union or the Economic Communities of West African States. ${ }^{43}$

3.7 Powers of a Copyright Owner. The author of a copyright work or the owner of Copyright enjoys certain exclusive rights. These rights operate as restrictive rights in that the author is empowered by Copyright to control the doing of certain actions and without his consent or authorization, such works may not be carried out. The doing of any of such works amount to an infringement of the right of the author or the copyright owner. Sections 6-9 of the Act provides for the general nature of copyright and provides for the exclusive actions that the author/copyright owner controls. These exclusive

\footnotetext{
${ }^{39}$ Id. at. Section 1 (4)

${ }^{40}$ Id. at. Section 2

${ }^{41}$ Id. at. Section 3

${ }^{42}$ Id. at. Section 4

${ }^{43}$ Id. at. Section 5
} 
actions include reproducing, publishing, performing, translating, making any cinematograph film or a record in respect of the work, distributing to the public for hire or for commercial purpose copies of the work, communicating to the public and making an adaptation of the work. The doing of any of the afore-mentioned actions amounts to copyright infringement which carry consequence both in the civil and criminal realms.

3.8 Infringement of Copyright. An important part of the legislation are the infringement provisions of the Act which provide for both civil and criminal actions which may be instituted simultaneously ${ }^{44}$ The Act specifically states amongst other things when prescribing copyright infringement that

Copyright is infringed by any person who without the licence or authorisation of the owner of the copyright (a) does or causes any other person to do an act, the doing of which is controlled by copyright; (b) imports or causes to be imported into Nigeria any copy of a work which, if it had been made in Nigeria would be an infringing copy under this section of this Act; ... ${ }^{45}$

In the event of an infringement, the copyright owner, assignee or exclusive licensee may bring an action before the Federal High Court and may claim for damages, injunctions and/or accounts. Ignorance is a defence to copyright infringement, but it must be proved that at the time of the infringement the defendant was actually unaware and had no reasonable grounds to suspect that copyright subsisted in the work. In such situations plaintiffs are not entitled to damages but rather account for profits in respect of the infringement. ${ }^{46}$

The Act criminalises copyright infringement with Section 20 of the Act providing conviction or fine and conviction and fine punishment to those found guilty. It provides that where a person is found guilty of making or causing to be made for sale, hire or other commercial purposes any infringing copy, or imports or causes to be imported into Nigeria a copy of any work which if it had been made in Nigeria would be an infringing copy, or makes, causes to be made or has in his possession, any plate, master

\footnotetext{
${ }^{44}$ Id. at. Section 24

${ }^{45} \mathrm{Id}$. at.Section 15 (1)

${ }^{46}$ Id. at.Section $16(3)$
} 
tape, machine, equipment or contrivances, for the purpose of making any infringing copy of any such work, such a person shall be liable to a fine of an amount not exceeding N1,000 for every infringing copy or a term of imprisonment not exceeding five years, or to both such fine and imprisonment. The criminal provisions with stiff penalties have been tested in the courts and have in many ways served as deterrence to further copyright infringements.

3.9 Court Convictions: In the cases of NCC V Godwin Kadiri, ${ }^{47}$ NCC V Michael Paul $^{48}$ and NCC V Emordi Henry Chukwuma ${ }^{49}$ all on charges infringing broadcast rights, the defendants were all found guilty. In the case of NCC V Godwin Kadiri, which held in the Benin judicial division, the defendant was sentenced to serve a $6 \frac{1}{2}$ years jail term with no option of fine and is being made to serve two jail terms. In NCC V Emordi Henry Chukwuma and NCC V Micheal Paul which were heard in the Abuja and Lafia jurisdictions of Nigeria, they were both sentenced upon conviction to pay fines of N10,000 and 5,100 respectively. Convictions have been made with regards to infringements of other works. In NCC V Nwoke Isreal ${ }^{50}$, the Lagos judicial division of the Federal High Court, convicted and sentenced the defendant to 1 year imprisonment without the option of fine for infringing upon literary rights. In NCC V. Anoke Celestine on charges bordering on infringements of sound recording and cinematograph film rights, the Benin judicial division of the federal high court sentenced the defendant to 10 months imprisonment

\section{Nigerian Copyright Commission}

4.1 Establishment. The 1999 amendment to the Act amongst other things established a body responsible for all matters affecting copyright in Nigeria known as the Nigerian Copyright Commission ${ }^{51}$. Although the Nigerian Copyright Act was passed in 1988, it was not until August 1989 that the

\footnotetext{
${ }^{47}$ NCC V GODWIN KADIRI, FHC/B/43C/2010, (Federal High Court, BeninCity. 17/12/2012).

${ }^{48}$ NCC V MICHAEL PAUL, FHC/LF/CR/2/2013, (Federal High Court, Lafia 3/10/2013).

${ }^{49}$ NCC V EMORDI HENRY CHUKWUMA, FHC/ABJ/CR/90/2013, (Federal High Court, Abuja. 19/06/2013).

${ }^{50}$ NCC V NWOKE ISREAL, FHC/L/159C/2013, (Federal High Court, Lagos 6/05/2013).

${ }^{51}$ Cap C28 (2004). Section 34
} 
Nigerian Copyright Council was established by virtue of Decree No.47 of 1988 and in 1996 government approved that it become the Nigerian Copyright Commission. The 1999 Amendment to the Act gave legislative effect to government's earlier approval. The Nigerian Copyright Council has it then was, was only saddled with copyright administrative responsibilities but with the amendments to the Act, its mandate was extended to cover enforcement and it became a full-fledged enforcement agency with perpetual succession. ${ }^{52}$ The Commission was given certain powers such as powers to grant compulsory licenses ${ }^{53}$, approval of organisations desirous of operating as collecting societies ${ }^{54}$, powers to make regulations subject to the approval of the Minister ${ }^{55}$ and powers to appoint copyright inspector inclusive of all police powers ${ }^{56}$. The combined effect of these provisions upgraded the status of the Commission from an administrative agency to an enforcement agency.

In addition to the responsibility provided in Section 34 (3) a, that is, to administer all matters affecting copyright in Nigeria, Section 34 (3) b-f of the Act provides for other functions of the Commission as follows:

b) monitor and supervise Nigeria's position in relation to international conventions and advise government thereon;

c) advise and regulate conditions for the inclusion of bilateral and multilateral agreements between Nigeria and any other country;

d) enlighten and inform the public on matters relating to copyright ;

e) maintain an effective databank on authors and their works;

f) be responsible for such other matters as relate to copyright in Nigeria as the Minister may from time to time direct.

\footnotetext{
52 Nigerian Copyright Commission NCC, About NCC Historical Background, available at http://www.copyright.gov.ng/index.php/about-us/ncc-historicalbackground.

${ }^{53}$ Cap C28 (2004). Section 37

${ }^{54}$ Id. at. Section 39 (1)

${ }^{55}$ Id. at. Section 45

${ }^{56}$ Id. at. Section 38. This section was introduced into the Act through the 1992 Amendment to the Act as Section 32A.
} 
4.2 Strategies. In carrying out the above functions, the Commission over time has adopted several strategies. In 2005, the Commission launched the Strategic Action Against Piracy (STRAP) which had three core components namely, mass enlightenment, rights administration and enforcement. This strategy also entailed an alternative dispute resolution (ADR) component tagged Copyright Litigation and Mediation Programme (CLAMP) which enable out of court settlements in the event of misunderstandings. ${ }^{57}$ The focus of STRAP when launched was to reduce the menace caused by piracy through strategic engagement with the general public and with stakeholders through targeted enlightenment programs, effective rights administration and where necessary through enforcement. The current administration of the Commission has re-adapted STRAP into what is now called a Medium Term Corporate Plan and Strategy (MTCPS) 2012-2014 and has the following 10 critical goals:

1. Improving the Policy and Legislative Framework for copyright Protection

2. Enhancing copyright Awareness and Education

3. Promoting Effective Rights Management and Regulation of copyright Industries

4. Proactive Enforcement Interventions

5. Strengthening Prosecutorial Activities

6. Strengthening Human and Institutional Capacity for Better Service Delivery

7. Deepening Strategic Engagement with Stakeholders

8. Expanding International Cooperation

9. Strong Public Private Partnership

10. Enhancing the Funding Profile of the Commission

The objective of the Commission either through STRAP, CLAMP or MTCPS is to harness and maximise the creative genius of Nigerians for national development and global influence through dissemination of copyright knowledge, effective rights administration and protection of rights. ${ }^{58}$

\footnotetext{
${ }^{57}$ Nigerian Copyright Commission NCC, STRAP and CLAMP - Nigeria Copyright Commission in Action, WIPO MAGAZINE September 2008.

${ }^{58}$ NCC 2012 Annual Report. (2012). See page 3 where it mentions the vision, mission and strategies of the Commission.
} 
4.3 Public Enlightenment. Enlightenment in any society is crucial because it provides requisite information and empowers ordinary citizens with the knowledge required to interact in the society. The esoteric nature of copyright makes it somewhat complex for the ordinary person to comprehend or appreciate what copyright is, what it does and how it works. Many Copyright owners do not understand what it is and how it works and hence do not know what rights they have and what users can do without the need for authorization. When copyright is infringed, right owners need to know what to do, who and where to go to. Similarly, if users feel cheated or do not understand certain issues regarding copyright, they ought to know where to go to seek relevant information and to get some sense of fairness and justice.

Under STRAP and now vigorously pursued under MTCPS, the Commission in furtherance of its vision to disseminate copyright knowledge set up the training arm of the Commission called the Nigerian Copyright Institute which is responsible amongst other things for training both the members of staff and the general public on issues of copyright. The institute carries out regular training programs for staff members, agencies of government, the judiciary, stakeholders, Intellectual Property lawyers and the general public. ${ }^{59}$ The Commission has also embarked on several enlightenment campaigns in furtherance of one of her core mandates as contained in Section 34 (2) d of the Act, that is to "enlighten and inform the public on matters relating to copyright;". Below is a list of some activities the Commission has been involved in as noted in its 2012 Annual Report.

1. Developed and placed Nigerian Copyright Commission's antipiracy jingle on DSTV Channels 114 and 118

2. Sustained periodic engagement with the press. Ten(10) press briefings were organized and several press releases issued on the state of copyright enforcement and administration in Nigeria.

3. Effectively implemented an interactive website that is constantly updated with information on the Commission's activities and relevant issues on copyright.

\footnotetext{
${ }^{59}$ Nigerian Copyright Commission NCC, Nigerian Copyright Institute, available $a \quad t$ www.copyright.gov.ng/index.php/2013-02-10-16-11-10/nigerain-copyrightinstitute-nci.
} 
4. Dissemination of copyright information at the 2012 edition of the Creativity Week co-organised with the Federal Ministry of Culture and Tourism.

5. Issuance of press release, production and distribution of posters to raise public awareness on copyright during this year's commemoration of World Intellectual Property Day on 26th April 2012. The World Intellectual Day is aimed at drawing attention to the phenomenal contributions of intellectual property to fasttracking the pace of development of the knowledge-driven economies of our modern world.

6. Celebration of the World Book and Copyright Day through issuance of press release and distribution of leaflets to raise public awareness on copyright. The World Book and Copyright Day is celebrated every 23rd April to acknowledge the significance of books and pay tribute to authors

7. Produced a variety of publicity materials on "Copyright System in Nigeria"; "Copyright Administration in Nigeria"; and a „Stop Piracy Now"e slogan.

8. Conducted anti-piracy sensitization campaigns at different piracy endemic markets across south-south and south-east geo-political zones in Nigeria, namely: Alaba International Market Lagos; Ochanja Market Onitsha and Ariara Market, Aba. It entailed a sensitization talk on the Commission's zero tolerance for piracy and distribution of publicity materials.

9. Organized a "Basic Copyright Training for the Media" for the staff of African Independent Television (AIT) on 6 June 2012.

10. Carried out anti-piracy sensitization exercises against book piracy in Zaria, Central Market, Chang chang Market, Kakuri and Sabo Market, Kaduna in September 2012. The public enlightenment focused on the ills of book piracy in the socio-economic growth and development of our country

11. Organized an induction training and sensitization workshop on copyright for students at the Nigerian Law School campuses in Abuja and Lagos in November 2012. The workshop exposed students to the basics of copyright. ${ }^{60}$

${ }^{60}$ NCC, NCC 2012 Annual Report. 2012. pages 10-11 where the actitives where listed under the heading "Enhancing Copyright Awareness and Education". 
4.4 Rights Administration. When the 1988 Copyright legislation was passed, the agitations leading to the legislation was centred on the outcry for greater protection of the rights of copyright owners. ${ }^{61}$ To ensure protection of these rights, the Commission has been saddled with the responsibility for all matters affecting copyright in Nigeria and this responsibility is both symbolic and significant. It is symbolic because the Commission has been made the designated reference point for all copyright matters in Nigeria and it is significant because whilst the Commission protects the rights of Copyright Owners, it simultaneously must protect the rights of user. It must therefore carry out this very sensitive role of maintaining an uncertain balance and must at the same time avoid delving into the arena of conflict. To achieve this symbolic and significant role, the Commission has been involved in and has also developed a number of mechanisms to administer copyright in Nigeria. These mechanism include administration of the following:

4.4.1 Copyright (Reciprocal Extension) Regulation 1972. This regulation was issued to enable the extension of copyright protection in works protected under the Act to countries to which Nigeria shares treaty obligations. The regulation was issued on the $1^{\text {st }}$ of February $1972 .{ }^{62}$

4.4.2 Copyright (Security Devices) Regulation 1999. Advancement in technology has enabled the invention of machines such as the photocopiers, printers, cassette recorders and other recording machines. These machines have made it much easier to reproduce contents and a lot of these contents are copyright protected. Section 21 of the Nigerian Copyright Act empowers the Commission to prescribe the use of any antipiracy device for use on any work in which copyright subsists. The intention is dual; first of which is to help the general public identify genuine products and secondly to curb the menace of piracy thereby providing authors an additional incentive for further creativity and for copyright owners to recoup their investments. In view of the above, the Commission issued the Copyright (Security Devices) Regulation 1999

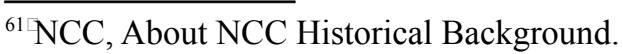

62 Nigerian Copyright Commission NCC, Copyright (Reciprocal Extension) Regulation $\quad 1972\left(\begin{array}{llll}1 & 9 & 7\end{array}\right)$, available http://www.copyright.gov.ng/images/downloads/Copyright\%20Reciprocal \%20Extension\%20Order\%201972.pdf.
} 
which majorly focused on the issuance of hologram stamps ${ }^{63}$. The regulation was issued on the $7^{\text {th }}$ of September $1999 .{ }^{64}$

4.4.3 Copyright (Video Rental) Regulations 1999: As the hiring and renting of video cassettes, cd's and dvd's became common in most parts of Nigeria, the need to consider the issue of sells, rentals and hiring of cinematograph films became imperative. The practice amongst those involved in video rental was to buy one video cassette, cd or dvd, reproduce the single copy into multiple copies and then rent them out to as many people as were willing to rent or hire them. To the ordinary mind, this meant that the general public appreciated the films and that the actors were becoming famous. On the contrary, what was happening was that illegal reproduction, sells, rentals and hiring of cinematograph (audio visual) works was taking place. These acts by virtue of the Nigerian Copyright laws constitute infringement of copyright. ${ }^{65}$ In addressing these new challenges, the Commission came up with the Copyright (Video Rental) Regulation. The regulation prescribed the issuance of a rental copy, which copy was meant to be produced by the copyright owners and would be purchased by the rental shops. ${ }^{66}$ The intention was that hiring, rentals, leasing or distributing in the public for commercial purposes would be regulated by the use of rental copies. A task force to monitor the rental shops would ensure compliance. This regulation was issued on the $7^{\text {th }}$ of September 1999. ${ }^{67}$ The major challenges to the regulation remain the failure of the industry to produce the prescribed rental copies. Another challenge is that the cost of purchasing cinematograph films in Nigeria have become very cheap due to competitions between optical discs

\footnotetext{
${ }_{63}$ Adebambo Adewopo, Intellectual property regime and the global financial crisis: lessons from Nigeria, 14 JOURNAL OF MONEY LAUNDERING CONTROL, 186 (2011).

${ }^{64}$ Nigerian Copyright Commission NCC, Copyright (Security Devices) Regulation 1999(1999), available at

http://www.copyright.gov.ng/images/downloads/Copyright\%20Security \%20devices\%20regulation\%201999.pdf.

${ }^{65}$ See Section 20 (2) a, b, c \& d.Cap C28 (2004).

${ }^{66}$ Regulation 5(1\&2) Nigerian Copyright Commission NCC, Copyright (Video Rental) Regulation 1999(1999), available at

http://www.copyright.gov.ng/images/downloads/Copyright\%20Video\%20rental \%20regulation\%201999.pdf.

${ }^{67}$ Id. at.
} 
manufacturing plants, Asian importation of pirated films and multiple cinematograph films on a single disc.

4.4.4 Copyright Notification Scheme. The notification scheme of the Commission is the mechanism through which a national copyright databank of authors and their works are kept. ${ }^{68}$ This scheme is not a mandatory registration system and does not confer any additional right than what copyright already confers. The scheme operates by encouraging authors to notify the Commission of the existence of copyright in their creative endeavours or the transfer of such copyright. The advantage of the scheme is that one's work is in the databank of the commission and in the event of litigation or uncertainty, it could constitute prima-facie proof of the date of the existence of the work. Works eligible for notification include, literary, musical, artistic, cinematograph films, sound recording and computer programmes and may be filed by the author, the copyright owner, an assignee, a licensee, an agent or a transferee. The Copyright Notification Scheme was introduced in 2005. ${ }^{69}$

4.4.5 Copyright (Optical Disc) Regulation 2006. This regulation became imperative to address the issue of piracy from the point of production. ${ }^{70}$ The discovery of two pirate plants in 2004 and 2005 necessitated the regulation. Prior to the discovery of the plants, works in which copyright subsists and embedded on optical discs were imported into Nigeria from Asia. The aim of the regulation was therefore to identify the sources of production and provide a legal regime for optical disc manufactures and producers to operate within a regulated legal framework. The regulation which requires all manufactures, importers and producers of optical discs and production parts to be registered with the Commission was issued on the $15^{\text {th }}$ of December $2006 .^{71}$

\footnotetext{
${ }^{68} \mathrm{~S} .34$ (2) e Cap C28 (2004).

${ }^{69}$ Nigerian Copyright Commission NCC, Copyright Notification Scheme(2005), available at $\mathrm{http} / / / \mathrm{www} . c o p y r i g h t . g o v . n g /$ index.php/regulatory-schemes/copyrightnotification.

${ }^{70}$ Adewopo, Journal of Money LaUndering Control, (2011).

71 Nigerian Copyright Commission NCC, Copyright (Optical Discs Plants) Regulation 2006. B 697-711 (2006), available at

http://www.copyright.gov.ng/images/downloads/Optical\%20Disc \%20Regulation.pdf.
} 
4.4.6 Copyright (Collective Management Organisation) Regulations 2007. Authors all over the world create works which users enjoy. Works made by authors find their way around the world and users continue to discover new works and use them. Considering that the human race is currently above 7 billion and the number is still on the increase, all 7 billion humans are potential users as well as potential creators of copyright works. Creative works enjoy copyright protection and except use of such works fall under some form of limitation and exception, the current legal regime for copyright requires that authorisation be obtained from the copyright owner prior to use. However, considering the vast number of copyright owners and users, it is impracticable to expect every user to track down every copyright owner and obtain the requisite authorisation. ${ }^{72}$ To address the above challenge, collective management organisations (CMO) exist to negotiate on behalf of copyright owners and grant licences to users as well as to collect payments from users and distribute royalties on an agreed rate to copyright owners. CMO's could therefore be considered as a one stop shop for clearing copyright contents in the interest of both copyright owners and the user publics. Considering the above and that Nigeria has a growing creative industry, the need for collective management organisations to serve both the copyright owner and the user community cannot be overemphasized. In 1993, the first regulation in this regards was issued and more recently, the Copyright (Collective Management Organisation) Regulations 2007 was issued which repealed the earlier regulation ${ }^{73}$. Two organisations are currently approved as collective management organisations, Reprographic Rights Organisation of Nigeria (REPRONIG) for the literary industry and Copyright Society of Nigeria (COSON) for the music industry.

4.4.7 Copyright (Levy on Materials) Order 2012. This is the most recent regulation issued by the commission. It takes its route from the provisions

${ }^{72}$ OLA, Copyright Collective Administration in Nigeria Lessons for Africa 8. 2013."The rationale for this system of management arises from the impracticability of managing these activities individually, namely the inability of the individual right owner to personally monitor and enforce all of his rights in every situation"

${ }^{73}$ Nigerian Copyright Commission NCC, Copyright (Collective Managemet Organisation) Regulation 2007(2007), available at

http://www.copyright.gov.ng/images/downloads/CMO\%20Regulation \%202007.pdf. The earlier regulation was called Copyright (Collecting Societies) Regulation 1993. 
of the Act in Section 40 which provide for levies on copyright materials and more directly mandates the payment of a levy on any material capable of being used to infringe copyright in a work. The intendment of the regulation is to create a platform where right-owners are able to receive some form of remuneration for the exploitation of their work however through a compulsory licensing methodology. The order prescribes levies payable in respect of materials used or capable of being used to infringe copyright. The rationale for the scheme lies in the need to ensure that right owners are properly remunerated for their works whilst at the same time enabling users exploit the work without any fear of contravening the legal provisions of any Law(s). The regulation was issued in 2012. ${ }^{74}$

4.5 Enforcement. In addition to public enlightenment and rights administration, the Commission uses enforcement mechanisms in tackling the challenges in the industry. It does this in collaboration with the traditional enforcement agencies in the country such as the Nigerian Police Force (NPF), the Nigerian Customs Services (NCS), the Economic and Financial Corruptions Commission (EFCC) and other non-enforcement sister agencies. The Commission shares information with other agencies and maximizes available platforms. The Commission embarks on regular anti-piracy raids, arrests and prosecution of pirates. These raids are conducted in conjunction with sister organisations and cover notorious areas such as well-known markets where the products are usually trafficked and the borders through which the products are known to be brought in or taken out. In the discharge of the Commission's enforcement mandate, the Commission carries out its operations through Copyright Inspectors who are empowered by Section 38 of the Act to enter, inspect and examine any premises they reasonably believe is being used for infringing activities. They are also empowered to seize items which they reasonably suspect to be infringing items as well as to arrest any person who they reasonably believe has committed an offence as stipulated by the Act.

\footnotetext{
7 Nigerian Copyright Commission NCC, Copyright (Levy on Materials) Order 2012 (2012) available at

http://www.copyright.gov.ng/images/downloads/REVISED\%20DRAFT\%20LEVY \%20ON\%20COPYRIGHT\%20MATERIALS\%20ORDER.pdf.
} 
In the Commission's 2012 annual report, successful enforcement activities were listed some of which are provided here-under as follows:

1. Conduct of over sixty (60) anti-piracy surveillances by the operatives of the Commission in piracy endemic locations across the country.

2. Carrying out of fifty-five 55 strategic anti-piracy operations against book, software, broadcast and audio-visual piracy in different piracy hotbeds across Nigeria, including Alaba International Market, Ojuelegba and Ijora in Lagos; Ariara Market Aba; Onitsha; Kano; Benin City and so on.

3. Arrest of 84 suspected pirates

4. Removal of 3,621,787 quantities of assorted pirated copyright works, comprising of books, software, DVDs, CDs etc from different piracy outlets and seaports across Nigeria with an estimated market value of four billion, three hundred and seventynine million, four hundred and thirty-one thousand Naira(N4,379,431,000).

5. Unprecedented confiscation of a total of thirteen (13) containers at different seaports across Nigeria in collaboration with the Nigerian Customs Service. Whereas, eleven (11) of the containers were stacked with pirated books of Nigerian and foreign authors, the remaining two (2) contained pirated musical and film works of local and foreign titles.

6. Drastic reduction in the activities of pirates, resulting in an over $50 \%$ increase in the profit margin of genuine investors in the copyright-based industries, creation of employment and a boost in the tax earnings of government from the industry practitioners. For instance, the Copyright Society of Nigeria (COSON), a collecting society for music and sound recordings shared a total of one hundred million Naira(N100,000,000) to their members as royalty paid for the use of music of its members. Distribution of such an amount of money is unprecedented in the annals of a collecting society in Nigeria.

7. Robust and enhanced monitoring of optical disc plants manufacturing outlets to ensure compliance with relevant extant laws and generate revenue for government. More specifically, three (3) inspections of optical disc replicating plants were conducted in the replicating facilities of ECOMAX, Dalla Music, Transerve 
Disc, Chronotec, Nasinma, Hoperising, Mediapro, Skymedia, Nira Sound Laboratries, Infobright Ltd and Alfa Magnetics within the period under review.

8. Public burning of 722 million units of pirated works and contrivances estimated at N6.5 billion, comprising literary, musical, film works and contrivances, including those from the broadcast industries, which were confiscated between 2007-2011. The purpose was to demonstrate the Commission's commitment to its zero tolerance policy on piracy and to send out a warning signal that piracy would no longer be a profitable venture. ${ }^{75}$

\section{The future of Copyright in Nigeria}

As noted at the beginning of this chapter, Nigeria is a nation rich in creativity. The pre-colonial era provides evidence of this in the artistic works seating in the museum in the western parts of the world. Today, Nigeria's Nollywood, the third largest film industry in the world is also evidence of Nigeria's rich and ingenious creativity. Nigeria's collective management organisation in music, copyright society of Nigeria (COSON) in 2011 and 2012 distributed royalties of 25 million naira in 2011 and 100 million naira in 2012 to members of the society ${ }^{76}$. The legal framework covering copyright in Nigeria has been instrumental to these developments as well as the STRAP and now MTCPS strategies adopted in carrying out mandates on copyright administration in Nigeria. The future of Nigeria like any other country is intrinsically tied to its ability to harness the potentials in her people as the world has since moved from dependence on an industrial based economy to a knowledge based economy with structural frameworks protected under the laws of intellectual property of which copyright is a core component. If Nigeria must play a significant role in this new frontier, there is the urgent need for strategic repositioning to ensure maximal benefits in today's global knowledge based economy and tomorrow's dynamic technologically driven market.

\footnotetext{
${ }^{75}$ NCC, NCC 2012 Annual Report. 2012. See pages 6-9

${ }^{76}$ COSON to Distribute 2013 Copyright Royalties, Vanguard(2013), available at http://allafrica.com/stories/201312121381.html.
} 
5. 1 Internet Treaties. In 1996, the World Intellectual Property Organisation passed the WIPO Copyright Treaty and the WIPO Phonogram and Phonographic Treaty, both referred to as the Internet treaties. The treaties were to bring international copyright issues in tandem with the growing use of the internet and technological advancements. Nigeria has since signed these treaties but is yet to domesticate them. If Nigeria will play a leading role in the emerging economy, there is the need to strategically domesticate these laws to enable copyright owners and the general public maximize the opportunities created by the advancements in technology. The whole idea of strategic domestication is to ensure that whatever laws are enacted should be primarily focused on favouring national development and on a secondary level should accommodate the interests of the wider global community. The general observation has been that many developing countries enact legislations which do not favour the nationals but rather favour the developed countries ${ }^{77}$. Such engagement with legislations cannot promote national development, hence the need for Nigeria to strategically domesticate the legislations.

\footnotetext{
77 Carolyn DeERe, The tRips Agreement and the Glboal Politics of Intellectual Property REForm In DEVEloping COUNTRIES 232 (Oxford University Press. 2009)."...the world's poorest countries adopt some of the world's highest IP standards at an earlier date than TRIPS required"
} 
5.2 TRIPS \& Flexibilities. The Uruguay round negotiations that produced in 1996, the Agreements on Trade Related Aspects of Intellectual Property (TRIPS) upgraded international copyright protection and places on all parties to the agreement obligations to provide certain minimum standard of protection to copyright works. Nigeria as a developing country has complied with most of these requirements but it is important to note that these requirements are majorly in the interest of developed and not developing countries. Articles 7 and 8 of the agreement provides some flexibilities to developing countries. Understanding these flexibilities and maximizing them in the interest of Nigeria's creative industry and copyright legislation will enable her play a stronger role in the present and coming economies. Nigeria's copyright future must therefore be one of strategic engagement for the development of the Nigerian creative industry through appropriate legislative reforms, strengthening international negotiation in the interest of Nigeria's creative industry and encouraging further development of creativity from the cradle to the grave.

\section{Open access and the future of Copyright}

6.1 Copyright and Open Access. In situating copyright in today's technologically enabled and driven society, there is the need to create some kind of synergy between copyright as a system and the open culture that favours free, online, unrestricted and immediate dissemination of information (Open Access). Whereas the current copyright system is restrictive by default, the open culture seeks ways to change that default. The underpinning for this change is the inability to access requisite information due to certain factors hindering access; factors which have been identified as "price, permission and technical". ${ }^{78}$ Price in the form of subscription costs by publishers as well as pay per view by specialised vendors. The obstacle created by permission is directly connected to the exclusive rights granted to copyright owners which restricts access to

\footnotetext{
${ }^{78}$ Peter Suber, Open ACCess 4-5 (MIT Press. 2012); See also, Budapest Open Access Initiative, Ten years on from the Budapest Open Access Initiative: Setting the default to open, available at http://www.opensocietyfoundations.org/openaccess/boai-10-recommendations.
} 
copyright materials except permission has been obtained. ${ }^{79}$ Technology provides the opportunity for right owners to place technologically enabled measures for protection on devices carrying their copyrighted contents as well as to monitor the use of such contents. By means of these measures, right owners are able to block access to their copyright materials and are also able to manage the use of their copyrighted contents. These technical possibilities may actually prove to be beneficial to right-owners but at the same time constitutes a hindrance to access; access to knowledge, access to information and access to peer-reviewed literature. In a global context access restriction constitutes hindrance to knowledge be they peerreviewed, educational, public sector information or purely entertainment information. For purposes of this chapter, access to information which are purely for entertainment purposes such as music, films and novels are not the focus because they can be considered as luxuries, non-necessities for fundamental development. On the other hand, access to peer-reviewed literature, educational resources and public sector information is cardinal for the development of any society.

6.2 Changing the Default from Closed to Open. Whereas the default setting for protecting knowledge under the current copyright regime is closed, (no access without permission), a movement seeks to change this default from closed to open for purposes of empowering the general public with access to peer-reviewed literature, access to educational resources, access to public sector information to the end that the general public will be properly equipped to make the best from available knowledge. Prior to the great exit of Nelson Mandela he noted that Education is the greatest tool for changing lives ${ }^{80}$. But what is the value of education when the knowledge required to gain education cannot be accessed? It is now commonly known that knowledge is power and that we live in a knowledge based economy ${ }^{81}$. Impact in this generation and probably the next will have a lot to do with

\footnotetext{
${ }^{79}$ OLA, Copyright Collective Administration in Nigeria Lessons for Africa 4. 2013.

80 Valerie Strauss, Nelson Mandela's famous quote on education, THE WASHINGTON POST 2013.

${ }_{81}$ World Bank, World Bank Announces Open Access Policy for Research and Knowledge, Launches Open Knowledge Repository, Press Release No:2012/379/EXTOP, (2012). Where the World Bank Group President Robert Zoellick said "knowledge is power"
} 
knowledge. Acquiring knowledge is therefore imperative for development and the currency to acquiring knowledge is access. No knowledge no development, no access, no knowledge. To ensure maximal utility of created knowledge, highest impact on such knowledge and greatest visibility to such knowledge amongst other things, the open access movement has concerned herself with shifting the access default from closed to open. In recognition of the importance of the current Copyright system, which empowers the copyright owner to restrict all others (except those falling under some form of limitation or exception) from exploiting copyright protected works without prior consenting having first been obtained, the movement relies on this right of the Copyright owner but this time not in a restrictive manner but rather in an enabling manner. It achieves this through open licensing systems which grants prior consent to prospective users. This system has been very successful in the software industry through the free open source software licenses such as GNU GPL ${ }^{82}$. In the content industry, there are several licenses but the creative commons licences appear to be the most popular. ${ }^{83}$

\footnotetext{
${ }^{82}$ Richard Stallman, The GNU Project at http://www.gnu.org/gnu/thegnuproject.html

${ }^{83}$ Brian Fitzgerald, A short Overview of Creative Commons (Sydney University Press 2007).
} 
In Nigeria's copyright future, embracing the open culture will be very instrumental to her development. However in adopting this culture, there is the need for proper understanding of the concepts though enlightenment and to adopt policies that would encourage further creativity within the Nigerian creative industry. This is very important because the open culture has the tendency of opening developing countries to become mere consumers and non-contributors to the world library. In order to benefit from the open access movement, Nigeria needs to strategically engage with the open culture for purposes of empowerment and not mere consumption. A mentality or attitude of mere consumption may seem to provide an easy win at the beginning but will eventually kill creativity and could no doubt bring about the eradication of the Nigerian culture and may produce the next dispensation of colonization. Proper engagement with the open culture will afford the opportunity to share the knowledge of the poor with the rich and the rich with the poor; it will also afford the highest level of visibility to works by Nigerian authors and allow for the possibility of global impact on locally generated works. The sharing culture typified by "Open" is the now and future for all form of content.

\section{Conclusion}

When the British carted away our creative works prior to our independence it may have seemed that our creativity had been stolen. The reality is that creativity is in deeply rooted in the people and their culture and it will take more than carting away a few items to steal ones national creativity. The passage into law of the 1970 Copyright Act signalled Nigeria's first domestic copyright law but it did not provide much in the opinion of Nigerian copyright owners and it led to the current 1988 copyright Act which has been amended twice to reflect the changing and dynamic nature of copyright. The several regulations that have been issued by the commission and the different strategies adopted the Nigerian Copyright Commission have in no small ways helped in the administration of copyright in Nigeria. The heightened convictions on copyright infringement will hopefully continue to serve as deterrence to others who think flagrant disregard for copyright is acceptable. The future of copyright for Nigeria will however lie in the ability of Nigeria to strategically engage with the international community in domesticating legal instruments and negotiating issues of interest for the development of Nigeria's creative industries. Cardinal to the development of copyright in Nigeria will be her ability to embrace the open culture by first understanding the concepts and taking 
steps to put in place policies that would enable the freedoms required for development. If the open culture is not embraced, copyright may be suffocated and relegated to a place of insignificance.

\section{References}

MFA, Museum of Fine Arts, Boston, Opens Benin Kingdom Gallery Showcasing Robert Owen Lehman Collection of Rare West African Art (2013), available at http://www.mfa.org/news/benin kingdom.

MFA, Benin Kingdom Gallery Gallery 172, Museum of Fine Arts Boston ( $\left.\begin{array}{llll}2 & 0 & 1 & 3\end{array}\right)$, available at http://www.mfa.org/collections/featuredgalleries/benin-kingdom-gallery.

Tajudeen Sowole, U.S. Museum Splits Benin Royal House, THE GUARDIAN, 29 September 2013. 2013.

Metropoitan Museum of Arts, Queen Mother Pendant Mask: Iyoba. On Display in Gallery 352., available at http://www.metmuseum.org/collections/search-the-collections/318622.

Federal Republic of Nigeria, About Nigeria, available at http://www.nigeria.gov.ng/2012-10-29-11-05-46.

Assessing the participation of domestic SMEs in the international production chain: The case of $\mathrm{Nu}$ Metro in Nigeria. (2010).

Chris Butler, FC74: The invention of the printing press and its effects at http://www.flowofhistory.com/units/west/11/FC74

Olukunle OlA, Copyright Collective Administration in Nigeria LESSONS FOR AFRICA (Springer. 2013).

Statute of Anne, 8 Anne c. 19 (1710).

WIPO, WIPO Administered Treaties, available at http://www.wipo.int/treaties/en/.

Nigerian Copyright Act, Cap C28 (2004).

WIPO, What is Intellectual Property, available at http://www.wipo.int/about-ip/en/.

BRIAN FitzGerald, et al., OAK LAW PROJECT NO.1: CREATING A Legal Framework For Copyright Management OF Open ACCess 
Within the Australian ACAdemic and Research Sector (Report FOR THE DEPARTMENT OF EDUCATION AND SCIENCE AND TRAINING (DEST) (2006).

Berne Convention for the Protection of Literary and Artistic Works, September 9, 1886, amended last on September 28, 1979 (September 9, 1886).

W IPO, Copyright Registration and Documentation, available at http://www.wipo.int/copyright/en/activities/copyright_registration/.

The Copyright Act of 1976 Title 17 of United States Code (1976).

NCC, General Information on Copyright Notification Scheme, available at http://www.copyright.gov.ng/index.php/regulatory-schemes/copyrightnotification.

Gurry Francis, Re-Thinking the Role of Intellectual Property, WIPO (2013).

Royal Irish Academy, MS 24.

World History,History of Nigeria, available at http://www.historyworld.net/wrldhis/plaintexthistories.asp?historyid=ad41.

ADEBAMBo AdEWOPO, NIGERIAN COPYRIGHT SYSTEM: PRINCIPLES AND PERSPECTIVES (Odade Publishers. 2012).

Jennifer Davis, Intellectual Property LaW (Nicola Padfield ed., Oxford University Press Third ed. 2008).

John Asein, Nigerian Copyright LaW and Practice (Books and Gavel Limited 2nd ed. 2012).

UNESCO, Universal Copyright Convention, with Appendix Declaration relating to Article XVII and Resolution concerning Article XI. Geneva, 6 September 1952, available at http://www.unesco.org/eri/la/convention.asp? $\underline{\mathrm{KO}=15381 \& \text { language }=\mathrm{E}}$.

Wikipedia,Music of Nigeria, available at http://en.wikipedia.org/wiki/Music of Nigeria\#The 1950s.2C .2760s and $.2770 \mathrm{~s}$. 
Tony Okoroj, Copyright Neighbouring Rights \& THE New Millionaires (THE TWISTS AND TURNS IN Nigeria) (Tops Limited. 2008).

Nigerian Copyright Commission, Survey of Copyright Piracy in NigERIA (Management Review Limited. 2008).

NCC V GODWIN KADIRI, FHC/B/43C/2010, (Federal High Court, Benin-City. 17/12/2012).

NCC V MICHAEL PAUL, FHC/LF/CR/2/2013, (Federal High Court, Lafia 3/10/2013).

NCC V EMORDI HENRY CHUKWUMA, FHC/ABJ/CR/90/2013, (Federal High Court, Abuja. 19/06/2013).

NCC V NWOKE ISREAL, FHC/L/159C/2013, (Federal High Court, Lagos 6/05/2013).

Nigerian Copyright Commission NCC, About NCC Historical Background, available at http://www.copyright.gov.ng/index.php/about-us/ncc-historicalbackground.

Nigerian Copyright Commission NCC, STRAP and CLAMP - Nigeria Copyright Commission in Action, WIPO MAGAZINE September 2008.

NCC 2012 Annual Report. (2012).

Nigerian Copyright Commission NCC, Nigerian Copyright Institute, available at http://www.copyright.gov.ng/index.php/2013-02-10-16-1110/nigerain-copyright-institute-nci.

Nigerian Copyright Commission NCC, Copyright (Reciprocal Extension) Regulation 1972(1972), available at http://www.copyright.gov.ng/images/downloads/Copyright\%20Reciprocal \%20Extension \%20Order\%201972.pdf.

Adebambo Adewopo, Intellectual property regime and the global financial crisis: lessons from Nigeria, 14 JOURNAL OF MONEY LAUNDERING CONTROL (2011). 
Nigerian Copyright Commission NCC, Copyright (Security Devices) Regulation 1999 (1999), available at http://www.copyright.gov.ng/images/downloads/Copyright $\% 20$ Security $\% 20$ devices $\% 20$ regulation $\% 201999$.pdf.

Nigerian Copyright Commission NCC, Copyright (Video Rental) Regulation 1999 (1999), available at http://www.copyright.gov.ng/images/downloads/Copyright\%20Video \%20rental\%20regulation\%201999.pdf.

Nigerian Copyright Commission NCC, Copyright Notification Scheme(2005), available at http://www.copyright.gov.ng/index.php/regulatory-schemes/copyrightnotification.

Nigerian Copyright Commission NCC, Copyright (Optical Discs Plants) Regulation 2006. B 697-711 (2006), available at http://www.copyright.gov.ng/images/downloads/Optical\%20Disc \%20Regulation.pdf.

Nigerian Copyright Commission NCC, Copyright (Collective Managemet Organisation) Regulation 2007(2007), available at http://www.copyright.gov.ng/images/downloads/CMO\%20Regulation \%202007.pdf.

Nigerian Copyright Commission NCC, Copyright (Levy on Materials) Order 2012(2012), available at http://www.copyright.gov.ng/images/downloads/REVISED\%20DRAFT \%20LEVY\%20ON\%20COPYRIGHT\%20MATERIALS\%20ORDER.pdf.

COSON to Distribute 2013 Copyright Royalties, Vanguard (2013), available at http://allafrica.com/stories/201312121381.html.

Carolyn Deere, The TRIPS Agreement and the Glboal Politics of InTELlectual Property REForm in DEVEloping countries (Oxford University Press. 2009).

Peter Suber, Open Access (MIT Press. 2012).

Budapest Open Access Initiative, Ten years on from the Budapest Open Access Initiative: Setting the default to open, available at 
http://www.opensocietyfoundations.org/openaccess/boai-10recommendations.

Valerie Strauss, Nelson Mandela's famous quote on education, THE WASHINGTON POST 2013.

World Bank, World Bank Announces Open Access Policy for Research and Knowledge, Launches Open Knowledge Repository, Press Release No:2012/379/EXTOP, (2012).

Richard Stallman, The GNU Project at http://www.gnu.org/gnu/thegnuproject.html Brian Fitzgerald, A short Overview of Creative Commons (Sydney University Press 2007). 